\title{
Genomic Based Characterization of Enterococcus Spp-An Emerging Pathogen Isolated from Human Gut
}

\section{Zumara younus}

Quaid-i-Azam University Islamabad: Quaid-i-Azam University

\section{Sagar M. Goyal}

University of Minnesota

\section{Vikash Singh}

University of Minnesota

\section{Aamer Ikram}

Department of Microbiology, Armed Forces Institute of Pathology, Rawalpindi Pakistan

Muhammad Imran ( $\nabla$ mmimran@qau.edu.pk)

Quaid-i-Azam University Faculty of Biological Sciences, Department of Microbiology https://orcid.org/0000-0002-5956-747X

\section{Short Report}

Keywords: coccus, Probiotics, Whole genome sequencing, Antimicrobial resiatnce

Posted Date: March 10th, 2021

DOI: https://doi.org/10.21203/rs.3.rs-214831/v1

License: (c) (i) This work is licensed under a Creative Commons Attribution 4.0 International License. Read Full License

Version of Record: A version of this preprint was published at Molecular Biology Reports on July 7th, 2021. See the published version at https://doi.org/10.1007/s11033-021-06540-5. 


\section{Abstract}

\section{Background}

Enterococci are ubiquitous microorganisms having diverse ecological niches but mostly prominently in gastrointestinal tract of humans and animals. Production of enterocins make them used as probiotics, but in last few years their role as probiotic become ambiguous. This ambiguity in their probiotic role is related to presence of virulence factors and antibiotic resistance genes. Moreover, these virulence traits are also known to be transfer genetically which make them opportunistic pathogens in gastrointestinal track. These reports suggest serious concerns related to enterococcus before using them as probiotics. In present study Whole-genome sequencing (WGS) of Enterococcus spp was done for checking presence of resistance and virulence genes, isolated from human gut.

\section{Methods and results}

Four human origin Enterococcus spp including Enterococcus faecalis, Enterococcus casseliflavus, and two Enterococcus gallinarum were isolated from human fecal samples, further cultured on blood and MacConkey agar. Sanger sequencing was done using Applied Biosystems 3730xI DNA Analyzer. These strains were further subjected to WGS using oxford nano pore technology MinION. Raw data was analyzed using free online tool epi2me. The Comprehensive Antibiotic Resistance Database (CARD) and RAST software's were used to look for presence of antibiotic resistance genes in these strains. Resistance determinants for clinically important antibiotics (vancomycin) and functional virulence factor genes were detected. G-view server was used for comparative genomics of all strains.

\section{Conclusion:}

The draft genomic sequencing of enterococcus suggested that Enterococcus faecalis, Enterococcus casseliflavus and Enterococcus gallinarum strains are opportunistic pathogens, having antibiotic resistance genes. All isolates have vancomycin resistance genes which they also expressed phenotypically. Some genes related to bacteriocin resistance were also present in E. casseliflavus and $E$. gallinarum.

\section{Introduction}

Enterococcus genus is important class of lactic acid bacteria (LAB) of the phylum Firmicutes that can survive in diverse ecological niches [1] including intestine of humans, animals and food products. Most of isolated strains of enterococci are proven to have probiotic properties and are consider as safe for host[2]. Probiotic bacteria are known for centuries mainly for their health benefits mostly in metabolic disorders, the Food and Agriculture Organization (FAO) and World Health Organization (WHO) have given some basic criteria before considering any strain as probiotic like tolerance level against gastrointestinal transit, production of antimicrobial peptides, susceptibility to antibiotics and having immunomodulation activity [3]. 
Several other genera of LAB like Aerococcus, Carnobacterium and Enterococcus were also studied due to their potential probiotic's capability[4], but sometimes due to presence of certain genes they role can be not as much positive as thought to be previously, genomic analysis is useful in identification and study of such genes, as genes not only effect molecular and metabolic routes but also give specific properties to probiotics [5].

Enterococcus is the main genera including 50 species that have probiotic properties, but many strains of enterococcus are known to cause disease in human as they are opportunistic pathogens. There is now an alarming increase of multidrug resistance among enterococci, mainly vancomycin resistance, more over they also have ability to transfer antibiotic and virulence genes [6].Whole genome sequencing is now becoming routine practice in many laboratories to characterize various genes related to antimicrobial resistance mainly in gram negative bacteria, very less data is available related to study of genome for antimicrobial resistance among gram positive bacteria[7]. Based upon this background its time of hour to do deep research on enterococcus virulence properties before using them as probiotic strains[8]. Moreover, research is also needed to differentiate between pathogenic and safe strains of enterococcus so we can use them as effective probiotic. So, this is a pilot study conducted to study genome of enterococcus isolated from human stool. The main aim of this study is to analyze Enterococcus virulence and antibiotic factors by using WGS technique.

\section{Material And Methods}

Stool sample collected from humans were stored at -80 , for isolation of common bacteria of gastrointestinal track. TTB (tetrathionate) glass bottle were used for incubation after which culturing was done on blood and MacConkey agar. Colony identification was done using Morphological and biochemical tests (Gram Staining; catalase and oxidase tests).

Kirby and Bauer disc diffusion test was used to determine antibiotic resistance in these strains[9]. For this, strains were first precultured in TSB medium and then colonies were dissolve in $2 \mathrm{~mL}$ of normal saline $(0.9 \% \mathrm{NaCl})$ to achieve $0.5 \mathrm{M} \mathrm{Mac}$ Ferland as turbidity standard. Antibiotics disks used were Vancomycin, Daptomycin, Gentamicin, Vancomycin, Tigecyline, Streptomycin, Nitrofurantoin, Linezolid, Ampicillin (Oxoid and Liofilchem). After $24 \mathrm{~h}$ at $37^{\circ} \mathrm{C}$ zone of inhibition was measured. Finally, colonies were stored at -80 till DNA extraction. Stool DNA was isolated by using commercial kit (Favrogen), Sanger sequencing was done to confirm presence of Enterococcus spp in all samples. Whole genome sequence of enterococcus spp were done using Oxford nano pore technology MinION using protocol (Lambdacontrol-sqk-Isk109-CDE_9062_v109_revl).

Sequence quality was assessed by FASTQC[7],[10] followed by online software https://epi2me.nanoporetech.com/workflow_instance. FASTA files were uploaded at RAST server for annotation, putative gene product identification[7, 11]. Moreover, to investigate the presence of antimicrobials resistance genes draft genome was uploaded at Metagenomic Rapid Annotations using Subsystems Technology, Genomes uploaded here can easily be accessed and analyzed by everyone. To 
visualize and compare the genome with other published Enterococcus Spp genomes at the time of analysis, G-view server (https://server.gview.ca/) was also used[7].

\section{Result And Discussion}

\section{Identification and physiochemical characterization:}

Enterococcus are commonly present in human gut and mostly are thought to be safe and used as probiotic. In present study enterococcus was isolated from GI track of human. Stool samples on culturing revolves Small, pinpoint cream or yellowish colonies on agar. Gram staining revealed presence of cocci, showing negative results for catalase and oxidase enzymes. API strips show presence of enterococcus in sample. Results from BLAST alignment shows confirmation of Enterococcus strains in culture. In order to characterize each strain of enterococcus WGS was performed. On analysis of WGS results sequencing data showed presence of Enterococcus faecalis, Enterococcus casseliflavus, Enterococcus gallinarum (in two cultures). These enterococci isolated from human gut were checked for their antibiotic resistances and variant genes.

Culture store at -80 was further confirmed using sanger sequencing via PCR amplification, further subjected to MinION and data analyzed by EPITOME showed different in genome size of all strains suggesting the fact that within enterococcus strains genetic variation is present.

\section{Genome size and features}

All four strains of enterococcus show different GC content ranging from 38 to 44 , genome size is also varying among strains from 1,167,642-3,508,906. Virulence and pathogenicity factors such as adhesins, invasions, pili, and hemolysin in enterococcus an make them human pathogen. The circular map of Enterococcus spp were generated using $\mathrm{G}$ view server figure 1, comparative genomic study was performed between different enterococcus spp.

\section{Metabolic network}

The metabolic pathway/genome database (PGDB) was created computationally with KEGG metabolic pathways in RAST annotation server. Genome size of all strains was between $1 \mathrm{M}-4 \mathrm{M}$, showing size diversity among different strains. GC content also varies among strains ranging from 38-43. These sizes are in agreement with Enterococcus spp genome present on NCBI.

We perform different type of analysis on this genomic data in order to evaluate Enterococcus strain as a potential probiotic. We found many genes related to bacteriocin production in strain QAU15(E.casseliflavus), i.e 13 genes are present related to bacteriocin production. Eight genes co-occur together in a cluster-based subsystem, among these one of gene is responsible to produce colicin V. Nine genes were present in strains E.casseliflavus and E.gallinarium for bacteriocin productions describing same role as above. Production of colicin $\mathrm{v}$ in these bacteria suggested their role in progression of 
gastrointestinal infection. Because many recent studies are now developing relationship between pathogenicity and colicinogeny in some different bacterial strains [12].

But only bacteriocins presence is not enough to declare Enterococcus as a non-suitable candidate for GARS. So next we do antibiotic resistance gene analysis of our strains, phenotypic data show vancomycin resistance among few strains of enterococcus. Using RAST software we found presence of different antibiotics resistance genes most common among all was vanXY. This is of significance importance clinically as it also expressed phenotypically in strains QAU14(E.facecalis),QAU15(E.casseliflavus) and QAU16(E.gallinarum). In vitro assay was performed to check resistance against commonly used antibiotics.

\section{Evaluation of Antibiotic Resistance:}

CARD The comprehensive antibiotic resistance database was used to check presence of antibiotic resistance genes. Enterococcus spp were then tested against commonly used antibiotics Daptomycin, Gentamicin Vancomycin, Tigecycline, Streptomycin, Nitrofurantoin, Linezolid and Ampicillin (Supporting table 1).

Results shows that QAU 17 (E. gallinarium), QAU 14 (E.faecalis),QAU15(E.casseliflavus) and QAU16(E.gallinarum) were resistance against vancomycin. E. faecalis and E. gallinarium were also resistance to linezolid, E.casseliflavus was resistance against ampicillin and vancomycin, and we then use CARP software to find presence of antibiotic resistance gene so we can see presence of antibiotic resistance genes in these isolates. VanXYC glycopeptides resistance gene cluster was observed in qau15 isolate suggesting strong antimicrobial resistance pattern here. E.gallinarium have AAC (6) li protein homology model belonging to aminoglycoside antibiotics class that work by antibiotics inactivation which is somehow expressed phenotypically that is its resistance towards vancomycin and linezolid. Three types of genes related to vancomycin resistance was found in E.gallinarium isolates i.e vanRC, vanXYC and vanC which are protein homolog and act against glycopeptides antibiotics. These results are verified by invitro analysis of drug susceptibility testing most strains were only resistance to vancomycin, suggesting vancomycin resistance as an intrinsic property of enterococcus genome.

Additional analysis of plasmid associated genes were also calculated using plasmid finder by RAST software, it shows presence of no genes associated with plasmid in all strains which can support evidence that these strains are not much involve $d$ in antibiotics resistance transfer genes, as plasmid have a central role in transfer of resistance genes.

\section{Conclusions}

Vancomycin and linezolid are most commonly used drugs against Enterococcus in hospitals, in our isolates we find out genes resistance to vancomycin only while two of Enterococcus strains QAU17(E.gallinarum) and QAU15(E.casseliflavus). QAU14(E.faecalis) and QAU 16 (E. gallinarum) are also resistance against Linezolid, which conclude presence of 23S rRNA mutations and horizontally acquired 
resistance genes cfr and optrA. Three chromosomally located clustered genes vanC1, vanXYC, and vanRC were detected in these strains except $E$. faecalis but always there is a chance that these resistance genes can be transmissible to other bacteria therefore it is suggested that more research is needed to study vanC1, van $X Y C$, and vanRC in enterococcus strains as they are reservoir for antimicrobial resistance genes. The WGS analyses approved that Enterococcus faecalis, Enterococcus casseliflavus, Enterococcus gallinarum isolates are not promising candidates for probiotic as they have antibiotic resistance and virulence genes, more comprehensive studies leading towards metabolic pathways are needed to be further evaluate enterococcus role as probiotic. Moreover, we use Oxford Nano pore technology MinION which proven to be time and cost effective for screening of normal gut flora of humans.

\section{Declarations}

\section{All Authors contribution:}

Ms. Zumara: All laboratory work done

Prof.Goyal: help in running WGS.

Dr. Vikash: data analysis

Prof. Aamer: Sampling make possible in MH/Help in AFIP Laboratory

Dr Imran: Basic idea, design experiment and data analysis

Consent to Participate (Ethics): All authors are agreed to participate in current study

Consent to Publish (Ethics): The work was approved was biological ethical committee of Quaid-i-Azam University Islamabad Pakistan

\section{References}

1. Byappanahalli, M.N., et al., Enterococci in the environment. Microbiology and Molecular Biology Reviews, 2012. 76(4): p. 685-706.

2. Franz, C.M., et al., Enterococci as probiotics and their implications in food safety. International journal of food microbiology, 2011. 151(2): p. 125-140.

3. Haney, E.F., S.C. Mansour, and R.E. Hancock, Antimicrobial peptides: an introduction, in Antimicrobial Peptides. 2017, Springer. p. 3-22.

4. Ring $\varnothing$, E., et al., Lactic acid bacteria in finfish-An update. Frontiers in Microbiology, 2018. 9: p. 1818.

5. Li, B., et al., Complete genome sequence of Enterococcus durans KLDS6. 0933, a potential probiotic strain with high cholesterol removal ability. Gut pathogens, 2018. 10(1): p. 32. 
6. Ben Braïek, O. and S. Smaoui, Enterococci: between emerging pathogens and potential probiotics. BioMed Research International, 2019. 2019.

7. Abd El-Baky, R.M., et al., Prevalence of virulence genes and their association with antimicrobial resistance among pathogenic E. coli isolated from Egyptian patients with different clinical infections. Infection and Drug Resistance, 2020. 13: p. 1221.

8. Rossolini, G.M., et al., Update on the antibiotic resistance crisis. Current opinion in pharmacology, 2014. 18: p. 56-60.

9. Hudzicki, J., American Society for Microbiology, Kirby-Bauer Disk Diffusion Susceptibility Test Protocol, 2013. 2015.

10. Tran, T.Q., et al. Development of hexagonal-z geometry capability in RAST-K for fast reactor analysis. 2019. Institut Teknologi Bandung Bahçeşehir University.

11. Aziz, R.K., et al., The RAST Server: rapid annotations using subsystems technology. BMC genomics, 2008. 9(1): p. 1-15.

12. Ozanne, G., L. Mathieu, and J. Baril, Production of colicin V in vitro and in vivo and observations on its effects in experimental animals. Infection and immunity, 1977. 17(3): p. 497-503.

\section{Tables}


Table 1

Presence of different antimicrobial genes and class of dug resistance and there mechanism according to CARP based upon WGS data.

\begin{tabular}{|c|c|c|c|c|c|}
\hline \multirow[t]{2}{*}{ S. NO. } & \multicolumn{3}{|l|}{ E. gallinarium } & \multirow{2}{*}{$\begin{array}{l}\text { E. gallinrum } \\
\text { QAU } 16\end{array}$} & \multirow{2}{*}{$\begin{array}{l}\text { E. } \\
\text { casseliflavus } \\
\text { QAU } 15\end{array}$} \\
\hline & QAU 17 & & & & \\
\hline RGI criteria & Perfect & strict & Strict & Strict & Strict \\
\hline ARO term & van $\mathrm{RC}$ & $\operatorname{van} \mathrm{XY}$ & van $\mathrm{C}$ & ACC(6)-li & VanXYC \\
\hline \multicolumn{6}{|l|}{ SNP } \\
\hline $\begin{array}{l}\text { Detection } \\
\text { criteria }\end{array}$ & $\begin{array}{l}\text { Protein } \\
\text { homolog } \\
\text { model }\end{array}$ & $\begin{array}{l}\text { Protein } \\
\text { homolog } \\
\text { model }\end{array}$ & $\begin{array}{l}\text { Protein } \\
\text { homolog } \\
\text { model }\end{array}$ & $\begin{array}{l}\text { protein } \\
\text { homolog model }\end{array}$ & $\begin{array}{l}\text { protein } \\
\text { homolog } \\
\text { model }\end{array}$ \\
\hline $\begin{array}{l}\text { AMR gene } \\
\text { family }\end{array}$ & $\begin{array}{l}\text { glycopeptide } \\
\text { resistance } \\
\text { gene cluster, } \\
\text { vanR }\end{array}$ & $\begin{array}{l}\text { glycopeptide } \\
\text { resistance } \\
\text { gene cluster, } \\
\text { vanR }\end{array}$ & $\begin{array}{l}\text { glycopeptide } \\
\text { resistance } \\
\text { gene cluster, } \\
\text { vanR }\end{array}$ & $\mathrm{AAC}\left(6^{\prime}\right)$ & $\begin{array}{l}\text { glycopeptide } \\
\text { resistance } \\
\text { gene cluster, } \\
\text { vanXY }\end{array}$ \\
\hline Drug class & $\begin{array}{l}\text { glycopeptide } \\
\text { antibiotic }\end{array}$ & $\begin{array}{l}\text { glycopeptide } \\
\text { antibiotic }\end{array}$ & $\begin{array}{l}\text { glycopeptide } \\
\text { antibiotic }\end{array}$ & $\begin{array}{l}\text { aminoglycoside } \\
\text { antibiotic }\end{array}$ & $\begin{array}{l}\text { glycopeptide } \\
\text { antibiotic }\end{array}$ \\
\hline $\begin{array}{l}\text { Resistance } \\
\text { mechanism }\end{array}$ & $\begin{array}{l}\text { Antibiotic } \\
\text { target } \\
\text { alteration }\end{array}$ & $\begin{array}{l}\text { antibiotic } \\
\text { target } \\
\text { alteration }\end{array}$ & $\begin{array}{l}\text { antibiotic } \\
\text { target } \\
\text { alteration }\end{array}$ & $\begin{array}{l}\text { antibiotic } \\
\text { inactivation }\end{array}$ & $\begin{array}{l}\text { antibiotic } \\
\text { target } \\
\text { alteration }\end{array}$ \\
\hline$\%$ identity & 100 & 99.4 & 98.83 & 99.4 & 79.8 \\
\hline $\begin{array}{l}\% \text { length of } \\
\text { reference } \\
\text { sequence }\end{array}$ & 100 & 88 & 100 & 100 & 100 \\
\hline
\end{tabular}


Table 2

genetic characterization of Enteroccocus strains on basis of WGS results shows presence of different genes related to its subsystem features.

\begin{tabular}{|c|c|c|c|c|}
\hline \multirow[t]{2}{*}{ Subsystem features } & $\begin{array}{l}\text { Enterococcus } \\
\text { faecalis }\end{array}$ & $\begin{array}{l}\text { Enterococcus } \\
\text { casseliflavus }\end{array}$ & $\begin{array}{l}\text { Enterococcus } \\
\text { gallinarum }\end{array}$ & $\begin{array}{l}\text { Enterococcus } \\
\text { gallinarum }\end{array}$ \\
\hline & QAU 14 & QAU 15 & QAU 16 & QAU 17 \\
\hline $\begin{array}{l}\text { Cofactors, vitamins, prosthetic } \\
\text { groups, pigments }\end{array}$ & 64 & 147 & 141 & 141 \\
\hline Cell wall and capsule & 96 & 155 & 149 & 149 \\
\hline Adhesion & 0 & 1 & 1 & 1 \\
\hline Toxins and superantigens & 0 & - & - & - \\
\hline $\begin{array}{l}\text { Bacteriocins, ribosomally } \\
\text { synthesized antibacterial } \\
\text { peptides }\end{array}$ & 0 & 13 & 9 & 9 \\
\hline $\begin{array}{l}\text { Resistance to antibiotics and } \\
\text { toxic compounds }\end{array}$ & 66 & 72 & - & - \\
\hline $\begin{array}{l}\text { Virulence, disease and defense- } \\
\text { no subcategory }\end{array}$ & 0 & - & - & - \\
\hline $\begin{array}{l}\text { Invasion and intracellular } \\
\text { resistance }\end{array}$ & 17 & 14 & 15 & 15 \\
\hline Potassium metabolism & - & 11 & 10 & 10 \\
\hline Photosynthesis & - & - & - & - \\
\hline Miscellaneous & 4 & 34 & 19 & 19 \\
\hline $\begin{array}{l}\text { Phages, prophages, transposable } \\
\text { elements, plasmids }\end{array}$ & 32 & 11 & 44 & 44 \\
\hline Membrane transport & 57 & 99 & 84 & 84 \\
\hline Iron acquisition and metabolism & 11 & 4 & 4 & 4 \\
\hline RNA Metabolism & 57 & 137 & 120 & 120 \\
\hline Nucleosides and nucleotides & 52 & 103 & 103 & 103 \\
\hline Protein metabolism & 158 & 230 & 200 & 200 \\
\hline Cell division and cell cycle & 7 & 54 & 42 & 42 \\
\hline Motility and chemotaxis & - & 24 & 15 & 15 \\
\hline Regulation and cell signaling & 24 & 44 & 41 & 41 \\
\hline Secondary metabolism & - & 6 & 1 & 1 \\
\hline
\end{tabular}




\begin{tabular}{|lllll|}
\hline Subsystem features & $\begin{array}{l}\text { Enterococcus } \\
\text { faecalis } \\
\text { QAU 14 }\end{array}$ & $\begin{array}{l}\text { Enterococcus } \\
\text { casseliflavus } \\
\text { QAU 15 }\end{array}$ & $\begin{array}{l}\text { Enterococcus } \\
\text { gallinarum } \\
\text { QAU 16 }\end{array}$ & $\begin{array}{l}\text { Enterococcus } \\
\text { gallinarum }\end{array}$ \\
\hline QAU 17 \\
\hline DNA metabolism & 122 & 189 & 110 & 110 \\
\hline $\begin{array}{l}\text { Fatty acids, lipids, and } \\
\text { isoprenoids }\end{array}$ & 4 & 99 & 75 & 75 \\
\hline Nitrogen metabolism & - & 13 & 6 & 6 \\
\hline Dormancy and sporulation & - & 4 & 2 & 2 \\
\hline Respiration & 42 & 61 & 46 & 46 \\
\hline Stress response & 40 & 77 & 60 & 60 \\
\hline $\begin{array}{l}\text { Metabolism of aromatic } \\
\text { compounds }\end{array}$ & - & 2 & 2 & 2 \\
\hline Amino acids and derivatives & 190 & 433 & 309 & 309 \\
\hline Sulfur metabolism & 4 & 55 & 38 & 38 \\
\hline Phosphorus metabolism & 23 & 32 & 33 & 33 \\
\hline Carbohydrates & 331 & 859 & 657 & 657 \\
\hline
\end{tabular}

\section{Figures}

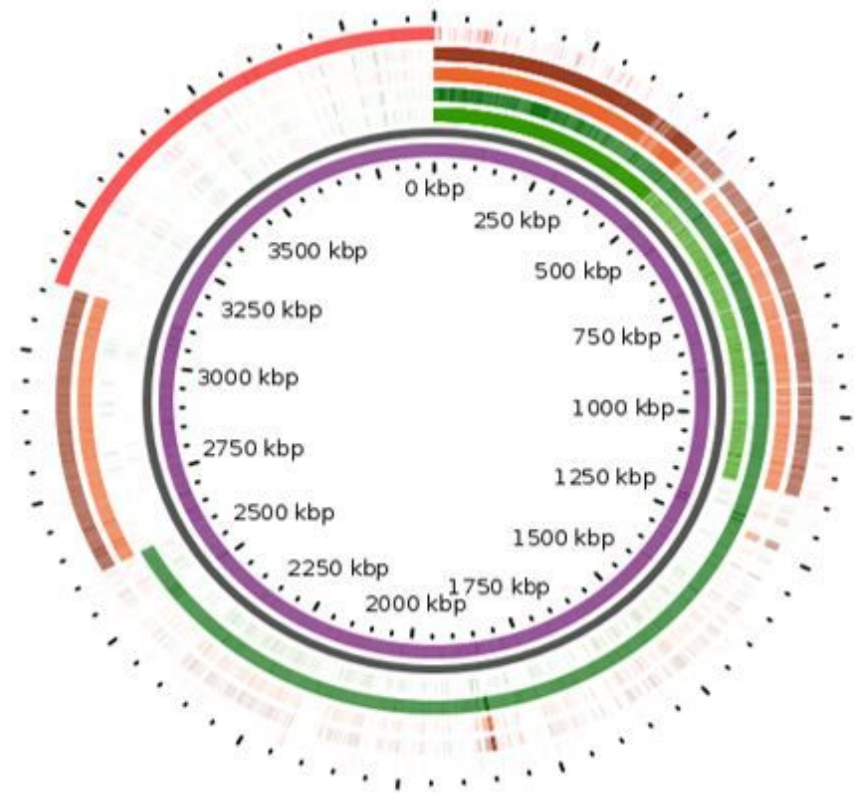

\begin{tabular}{|l}
\hline QAU_14.gbk \\
QAU17.gbk \\
QAU16.gbk \\
QAU15.gbk \\
ENTEROGCF_000157255.1_ASM15725V1_genomic.gbff \\
pangenome.gbk
\end{tabular}




\section{Figure 1}

Circular map of Enterococcus spp showing comparative genomics between different species. QAU 14 (E. faecalis), QAU 15(E. casseliflavus), QAU 16 (E. gallinarum) and QAU 17(E. gallinarum II) with already reported genome of Enteroccus on NCBI

\section{Supplementary Files}

This is a list of supplementary files associated with this preprint. Click to download.

- SUPPORTINGDOCUMENTS.docx 